\title{
Correction to: The Prison and the Factory (40th Anniversary Edition)
}

\section{Correction to:}

Dario Melossi and Massimo Pavarini, The Prison and the Factory (40th Anniversary Edition), DOI 10.1057/978-1-137-56590-7

The original version of this book was inadvertently published without the Edition number in the title page and incomplete Copyright Comment in the copyright page. The correction to this book can be found at DOI 10.1057/978-1-137-56590-7_8

The updated original online version of the book can be found at DOI 10.1057/978-1-137-56590-7 